\title{
状況依存的焦点モデルに基づく居住地選択行動における フレーミング効果分析
}

\author{
$\bigcirc$ 藤井 聡 $^{1} \cdot$ 谷口綾子 ${ }^{2} \cdot$ 浅見知秀 $^{2} \cdot$ 竹村和久 ${ }^{3}$ \\ ( ${ }^{1}$ 京都大学大学院工学研究科, ${ }^{2}$ 筑波大学大学院システム情報工学研究科, ${ }^{3}$ 早稲田大学文学部) \\ Key words：焦点化仮説，焦点化の状況依存性，フレーミング効果
}

意思決定者の“注意”の向け方の相違によって，フレー ミング効果をはじめとした意思決定上の諸効果を理論的 に説明する，「状況依存焦点モデル」が提案されている（竹 村, 1994 ; 藤井・竹村, 2001). 状況依存的焦点モデルは, 選択肢集合からの選択問題を取り扱うもので，各選択肢 $i$ の価值水準 $U_{i}$ を想定すると共に，意思決定者はその $U_{i}$ が 最大の選択肢を選択するものと想定する．そして，その価 值関数として, $U_{i}=U\left(X_{\mathrm{i}}, \boldsymbol{a}\right)$ という関数を想定する。 こ こに，Xi選択肢 $i$ の価值水準に影響を及ぼす変数べクト ルであり， $\boldsymbol{a}$ はパラメータベクトルである。こうした仮定 はいずれも，プロスペクト理論や期待効用理論と同様のも のであるが，状況依存焦点モデルは，このパラメータベク トル $\boldsymbol{a}$ が状況に依存して変容すると仮定する点が最大の特 徴である。そして，そのパラメータの変容について，「焦 点化仮説」（藤井・竹村，2001）を措定する.この焦点化 仮説とは，選択肢や箇々の属性などに対する意思決定者の

“注意”の向け方の相違によって，パラメータ $\boldsymbol{a}$ が変化す るという仮説である．さらに，その意思決定者の注意の仕 方は，意思決定の文脈や環境等の諸条件によって影響を受 けると想定される。これが，「焦点化の状況依存性仮説」

(藤井・竹村, 2001) であり, 数理的には $\boldsymbol{a}=\Psi(\theta)$ と 記述できる.ここに，日は状況的要因を表す変数ベクトル， $\Psi($ )は $a$ の $\theta$ に対する状況依存性を意味する関数である.

既往研究では, 焦点化仮説ならびに焦点化の状況依存性 仮説を支持する結果が，主として統制された種々の室内実 験によって示されている（藤井・竹村, 2001 ; 藤井・竹村 • 吉川，2005）。ただし，これまでの仮説検証において，実 際の生活空間における現実の選択行動を対象としたフィ ールド実験は行われてきていない. 本研究では, こうした 認識から, 状況依存的焦点モデルが想定する意思決定と注 意に関する仮説の妥当性を検証するフィールド実験を行 うものである。

方法 本研究では, 大学生の居住地選択行動に着目し, 状 況依存的焦点モデルの理論仮説の妥当性を検証する. 実験 では, 筑波大学の 1 年生を対象とした。筑波大学では, 学 部 1 年生の多くが大学敷地内にある学生宿舎に入居する. 学生宿舎は, 1 年生に優先的に提供されるため, 2 年生に 進級する際, 多くの学生が学生宿舎を出て大学周辺のアパ ートに入居する. ついては本研究では, 2008 年 3 月末につ くば市内のアパートへの引つ越しを予定している筑波大 学の学部 1 年生 72 名を対象とした。

実験ではこの 72 名全員に, 筑波市内の賃貸物件のリス 卜を提供した。このリストは, 家貨や面積, 最寄りバス停 までの徒歩時間などの各物件の属性情報が，「白黒の文
字」で掲載されているものである.ただし，72 名の内 34 名のリストには, バス停までの所要時間が 3 分以下の物件 には,「赤色」の「バス停便利マーク」を付与した（バス 利便性強調群）。さらに，72名の内の別の 20 名には，バ ス利便性強調群に配布したリス卜に加えて，バス停が便利 な物件の優位性を訴える説得冊子をあわせて配布した（バ ス利便性動機付け群）。なお, 残りの 18 名には, バス停 便利マークが記載されていない白黒のリストの夕を配布 した（統制群）。

結果と考察 その後, 同年 4 月に各参加者の居住地住所を 確認した。 そして，その住所情報から最寄りバス停までの 距離を測定し, バス停までの距離が 3 分以内か否かを測定 したところ, 表 1 の様になった。この結果は, 提示する属 性情報が同じであっても, 特定の属性（すなわち, バス停 までの距離）を認知的に強調したり，さらに動機的に強調 することで，その属性を重視した意思決定が下される傾向 を示している.

表 1 各群のバス停までの距離に関する分布

\begin{tabular}{lcccc}
\hline & \multicolumn{3}{c}{ バス停までの距離 } & \\
& 3 分以上 & 3 分未満 & (3 分未満の割合) \\
\cline { 2 - 2 } 統制群 & 15 & & 3 & $(16.7 \%)$ \\
バス利便性強調群 & 23 & & 11 & $(32.4 \%)$ \\
バス利便性動機付け群 & 11 & & 9 & $(45.0 \%)$ \\
\hline
\end{tabular}

ここで, 価值関数として, $U_{i}=a B D_{i}+\varepsilon_{\mathrm{i}}$ というバス停ま での距離の遠近で変化するランダム効用を仮定する．ここ に $B D_{i}$ はバス停までの距離が 3 分以下か否かのダミー変数 であり, $\varepsilon_{\mathrm{i}}$ はバス停までの距離以外の要因の効果を現す䛊 差項であり，ガンベル分布を仮定する。ここで，パラメー タ $a$ は状況に応じて異なるパラメータであると想定し,$a=$ $a_{0}+a_{1} C_{c o g}+a_{2} C_{m o t}$ と仮定する。 ここに $C_{c o g}$ はバス停便利 マークが付与されるか否かの直行対比変数, $C_{m o t}$ はバス停 便利マークを付与した上で動機付け冊子が配布されたか 否かの直行対比変数である.ここで, これらのパラメータ をガンベル分布の IIA 特性を活用して二項ロジットモデル の考え方に基づいて推定したところ， $a_{1} ， a_{2}$ 共に正の值と なり, 特に $a_{1}$ の推定值は片側検定で有意傾向となった（B $=0.201, p=.065)$. すなわち，バス停までの距離が近いか 否かという要因のパラメータが, 赤いマークでその要因を 強調することで大きくなる, という状況依存的焦点モデル の基本仮説を支持する傾向が確認された。この結果は，状 況依存焦点モデルの基本的な考え方が現実の選択行動に 妥当し得る可能性を示唆するものである.

(主な参考文献)

藤井聡，竹村和久：リスク態度と注意一状況依存焦点モデルによるフレー ング効果の計量分析一, 行動計量学,28(1), pp. 9-17, 2001.

藤井 聡・竹村和久・吉川肇子:囚人のジレンマゲームにおける意思決定と焦点 化, 理論心理学研究, 7 (1), pp. 32-35,

竹村和久 (1994). フレーミング効果の理論的説明ーリスク下における意思 決定の状況依存的焦点モデル，心理学評論, 37(3), 270-291.2005. 